\title{
PELAKSANAAN AKREDITASI SEKOLAH DASAR NEGERI
}

\author{
Antonius \\ Fakultas Ilmu Sosial dan Ilmu Politik Universitas Kapuas \\ Email Antonius@gmail.com
}

\begin{abstract}
ABSTRAK: Akreditasi sekolah adalah proses penilaian secara komprehensif terhadap kelayakan dan kinerja satuan dan/atau program pendidikan, yang dilakukan sebagai bentuk akuntabilitas publik. Di dalam proses akreditasi, sebuah sekolah dievaluasi dalam kaitannya dengan arah dan tujuannya, serta didasarkan kepada keseluruhan kondisi sekolah sebagai sebuah instituasi belajar. Walaupun beragam perbedaan dimungkinkan terjadi antar sekolah, tetapi sekolah dievaluasi berdasarkan standar tertentu. Dengan demikian dapat dikatakan bahwa proses akreditasi dalam makna proses adalah penilaian dan pengembangan mutu suatu sekolah secara berkelanjutan. Akreditasi dalam makna hasil menyatakan pengakuan bahwa suatu sekolah telah memenuhi standar kelayakan pendidikan yang telah ditentukan. Akreditasi sebagai langkah agar sekolah kedepan memiliki semangat berkompetensi satu dengan yang lainnya. Kompetensikompetensi ini biasa dicapai melalui proses yang mencangkup pemberian layanan implementasi kurikulum/ proses belajar-mengajar, penciptaan lingkungan sekolah yang kondusif, penyelenggaraan administrasi dan manajemen sekolah yang baik, peran serta masyarakat, dan pembinaan okelembagaan sekolah yang baik, peran serta masyarakat, dan pembinaan kelembagaan sekolah yang baik; serta dengan dukungan pembiayaan yang memadai, tenaga yang sesuai dengan kebutuhan baik segi kuantitas maupun kualitas, dukungan sarana dan prasarana yang memadai dan akhirnya peserta didik secara aktif mengikuti seluruh kegiatan pembelajaran dengan memenfaatkan sumber belajar yang tersedia.
\end{abstract}

\section{Kata Kunci: Akreditasi Sekolah}

Program atau satuan pendidikan pada jalur formal pada jenjang pendidikan dasar dan menengah diakreditasi oleh BANS/ M (Badan Akreditasi Nasional Sekolah/Madrasyah) yang pada tingkat propinsi dibentuk oleh gubernur. Menurut Luhulima (2007:231) menyatakatakan bahwa "Akreditasi sekolah yang sebenarnya mempunyai pengertian sebagai proses penilaian secara komprehensif terhadap kelayakan dan kinerja lembaga atau suatu program pendidikan dilakukan sebagai bentuk akuntabilitas publik, alat regulasi diri di mana sekolah mengenal kekuatan dan kelemahan serta terus menerus meningkatkan kekuatan dan memperbaiki kelemahannya". Pengertian ini akan lebih memberikan makna dalam hasil sebagai suatu pengakuan, suatu sekolah telah memenuhi standar kelayakan yang ditentukan. Undang-Undang Nomor 20 Tahun 2003 Tentang Sistem Pendidikan Nasional, perlu dilakukan pengembangan sekaligus membangun sistem pengendalian mutu pendidikan melalui empat program yang terintegrasi, yaitu standarisasi, evaluasi, akreditasi dan sertifikasi. Standarisasi pendidikan mempunyai makna sebagai upaya penyamaan arah pendidikan secara nasional yang memiliki keleluasan dan keluwesan dalam implementasinya. Evaluasi merupakan suatu proses kontinu dalam memperoleh data maupun informasi guna pengambilan suatu keputusan. Akreditasi merupakan suatu pengakuan terhadap kinerja sekolah yang diwujudkan dengan adanya sertifikasi yang dikeluarkan suatu lembaga mandiri dan profesional.

Mengingat yang diakreditasi adalah sekolah yang merupakan sistem dari berbagai komponen dan saling terkait dalam pencapaian komponen sekolah, maka sesuai Keputusan Menteri Pendidikan Nasional Nomor 087/V/2002 Tanggal 14 Juni 2004 Tentang Akreditasi Sekolah, komponen sekolah yang menjadi bahan penilaian adalah yang dikembangkan dari kualitas sekolah yaitu kurikulum dan proses belajar mengajar, manajemen sekolah, organisasi/kelembagaan sekolah, sarana dan prasarana, ketenagaan, pembiayaan, peserta didik, peran serta masyarakat dan lingkungan/kultur sekolah. Hal tersebut dipertegas oleh Undang-Undang Nomor 20 Tahun 2003 Tentang sistem Pendidikan Nasional, tentang akreditasi yang berbunyi : Akreditasi dilakukan untuk menentukan kelayakan program dan satuan pendidikan pada jalur pendidikan formal dan nonformal pada setiap jenjang dan jenis pendidikan; Akreditasi terhadap program dan satuan pendidikan dilakukan oleh lembaga mandiri yang berwenang sebagai bentuk akuntabilitas public; Akreditasi dilakukan atas dasar criteria yang bersifat terbuka; Ketentuan mengenai akreditasi sebagaimana dimaksud dalam ayat 1 , ayat 2 , dan ayat 3 diatur lebih lanjut dengan peraturan pemerintah. 
Kebijakan akreditasi sekolah juga didasarkan pada Keputusan Menteri Pendidikan Nasional Nomor 087 Tahun 2002 Tentang Akreditasi Sekolah dan Keputusan Menteri Pendidikan Nasional Nomor 039 Tahun 2003 Tentang Badan Akreditasi Sekolah Nasional. Dalam Keputusan tersebut juga diuraikan tentang prinsip-prinsip yang dijadikan pijakan dalam melaksanakan akreditasi sekolah adalah objektif, efektif, komperhensif, memandirikan, dan kaharusan yangdi dalamnya mengandung penerapan prinsip keadilan. Prinsif-prinsif akreditasi sekolah meliputi objektif. Akraditasi sekolah pada hakekatnya merupakan kegiatan penilaian tentang kelayakan dan kinerja penyelenggaraan pendidikan yang ditunjukkan oleh suatu sekolah. Dalam pelaksanaan penilaian ini berbagai aspek yang terkait dengan kinerja dan kelayakan diperiksa untuk memperoleh informasi tentang keberadaannya. Agar hasil penilaian itu dapat menggambarkan kondisi yang sebenarnya untuk dibandingkan dengan kondisi yang diharapkan maka dalam prosesnya digunakan indikator-indikator yang dikaitkan dengan kriteria-kriteria yang diinginkan sebagai dasar penilaian. Efektif. Dalam \$pelaksanaan akreditasi sekolah, hasil yang diperoleh harus mampu memberikan informasi yang bisa digunakan sebagai dasar dalam pengambilan keputusan yang tepat oleh pihak-pihak yang terkait, seperti kepala sekolah dalam rangka melakukan perencanaan atau peningkatan mutu, dan pihak pemrintah maupun masyarakat dalam rangka memfasilitasi upaya peningkatan kelayakan dan kinerja sekolah itu. Komprehensif.

Dalam pelaksanaan akreditasi sekolah fokus penilaian tidak hanya terbatas pada asperkaspek tertentu saja, tetapi meliputi berbagai aspek yang bersifat menyeluruh. Dengan demikian hasil yang diperoleh dapat menggambarkan secara utuh kondisi kelayakan dan kinerja sekolah tersebut. Kelayakan dan konerja ini terutama ditinjau dari misi utamanya yaitu memberikan layanan pendidikan dalam rangka membangun generasi yang memiliki pengetahuan dan kemampuian untuk menjadi diri sendiri, serta dapat menjalani hidup bersama orang lain. Memandirikan. Kewenangan melakukan akreditasi sekolah berada pada lembaga eksternal di luar sekolah yang secara teknis bersifat mandiri. Namun demikian. Proses akreditasi mencakup kegiatan evaluasi diri oleh sekolah dengan menggunakan instrument yang disediakan oleh lembaga eksternal tersebut. Hasil evaluasi diri dapat digunakan untuk menentukan tingkat kelayakan sekolah dibandingkan standar kelayakan nasional yang dijadikan pagu.

Dengan mengetahui kelayakan sekolah, selanjutnya kepala sekolah yang belum mencapai tingkatan minimal dari pagu itu. Dengan demikian proses akreditasi akan berdampak bagi sekolah yang bersangkutan untuk dapat mengetahui kekuatan dan kelemahannya, dan berupaya memperbaiki dan meningkatkan mutu kelayakan dan kinerjanya secara mandiri. Keharusan. Akreditasi dilakukan untuk setiap sekolah, baik sekolah swasta maupun negeri. Sekolah yang akan diakreditasikan mengajukan permohonan terlebih dahulu kepada Badan akreditasi sekolah untuk dilakukan akreditasi. Menurut Nugroho (2008:56) menyatakan bahwa akreditasi sekolah mempunyai beberapa tujuan dalam rangka Memberi informasi bahwa sebuah sekolah atau sebuah program dalam suatu sekolah telah atau belum memenuhi standar kelayakan dan kinerja yang telah ditentukan. Membantu sekolah melakukan evaluasi diri dan menentukan kebijakan sendiri dalam upaya peningkatan mutu. Membimbing calon peserta didik, orang tua, dan masyarakat untuk mengidentifikasikan sekolah yang memiliki prestasi dalam suatu bidang tertentu yang mendapat pengakuan masyakarat. Membantu sekolah dalam menentukan dan mempermudah kepindahan peserta didik dari satu sekolah ke sekolah lain, pertukaran guru, dan kerjasama yang saling menguntungkan. Membantu mengidentifikasi sekolah dan program dalam rangka pemberian bantuan pemerintah, investasi dana swasta dan donator atau bentuk bantuan lainnya.

Standar akreditasi sekolah adalah kriteria tertentu yang harus dipenuhi sesuai dengan komponen-komponen pendidikan pada setiap satuan pendidikan TK, TKLB, SD, SDLB, SMP, SMPLB, SMA, SMK dan AMLB. Setiap sekolah harus memenuhi standar minimal yang telah ditetapkan oleh Badan Akreditasi Sekolah Nasional (BABNAS). Sekolah yang memenuhi standar minimal akan dinyatakan terakreditasi dan yang tidak memnuhi dinyatakan tidak terakreditasi. Karena standar yang digunakan untuk mengakreditasi sekolah adalah standar minimal, BASNAS mendorong agar sekolah mencapai standar merupakan sesuatu yang bersifat dinamis sejalan dengan perkembangan dan tuntutan, maka tingkatan standar juga akan berubah sesuai dengan perkembangan dan tuntutan pendidikan dimasa depan. Akreditasai dilakukan melalui tindakan membandingkan kondisi sekolah dalam kenyataan dengan criteria (standar) yang telah ditetapkan. Mengingat sekolah sebagai sistem yang tersusun dari komponen-komponen yang saling terkait untuk mencapai tujuan sekolah, maka standar yang dimaksud harus disusun berdasarkan komponenkomponen sekolah.

Sesuai dengan Keputusan Menteri Pendidikan Nasional Nomor 087 Nomor Tahun 2002 Tentang Akreditasi Sekolah, komponenkomponen yang menjadi bahan penilaian adalah: (1). Kurikulum dan Proses Pembelajaran, (2). 
Administrasi dan Manajemen Sekolah, (3). Organisasi dan kelembagaan sekolah, (4).Sarana dan Prasarana ,(5). Ketenagaan, (6). Pembiayaan, (7). Peserta didik, (8). Peran serta masyarakat, (9). Lingkungan dan Budaya sekolah. Setiap komponan dijabarkan kedalam berbagai aspek dan indikator. Selanjutnya indikator-indikator yang dikembangkan tersebut dijadikan acuan dalam pengembangan instrument dan akreditasi penilaian yang digunakan dalam proses akreditasi sekolah. Sekolah melaksanakan kurikulum nasional dan kurikulum muatan lokal atau pilihan sesuai dengan ketentuan yang berlaku. Dalam pelaksanaannya sekolah berpegang pada dokumen kurikulum dan silabus yang dikembangkan dengan mengacu pada dokumen kurikulum tersebut. Sekolah memiliki kalender pendidikan dan jadwal pembelajaran yang jelas. Menurut Nugroho (2008:221) menyatakan bahwa "Standar kurikulum dibuat untuk memberikan jaminan kepada masyarakat bahwa apa yang diperoleh benar-benar konsisten dengan prinsip dan tujuan pendidikan nasional sebagaimana tertuang dalam kurikulum nasional". Meskipun sekolah diperkenankan untuk mengembangkan atau melaksanakan kurikulum yang menjadi ciri khas dari sekolah yang bersangkutan, namun kurikulum nasional tetap harus dilaksanakan sepenuhnya.

Sekolah memiliki tenaga kependidikan professional yang jumlahnya memadai, dengan kualifikasi, kompetensi dan tingkat kesesuaian berdasarkan peraturan yang berlaku. Guru adalah mereka yang berkualifikasi sebagai pendidik dan pengelola pendidikan. Pendidik bertugas merencanakan, melaksanakan dan menilai serta mengembangkan proses pembelajaran. Tenaga kependidikan meliputi guru, konselor, kepala sekolah dan sebutan lain yang sesuai dengan kekhususannya. Secara umum, tenaga kependidikan sekolah bertugas melaksanakan perencanaan, pembelajaran, pembimbingan, pelatihan, pengelolaan, penilaian, pengawasan, pelayanan teknis dan kepustakaan, penelitian dan pengembangan hal-hal praktis yang diperlukan untuk meningkatkan mutu proses pembelajaran. Menurut Tilaar (2006:116) “Tenaga kependidikan merupakan jiwa sekolah dan sekolah hanyalah merupakan wadah. Karena itu, tenaga kependidikan merupakan kunci bagi suksesnya pengembangan sekolah.

Menurut Tilaar sekolah memiliki: (1) tenaga kependidikan yang cukup jumlahnya; (2) kualifikasi dan kompetensi yang memadai sesuai dengan tingkat pendidikan yang ditugaskan; (3) tingkat kesesuaian dalam arti kemampuan yang dimiliki oleh tenaga kependidikan sesuai dengan bidang kerja yang ditugaskan; dan (4) kesanggupan kerja yang tinggi. Setiap tenaga kependidikan berkewajiban (1) menjaga nama baik lembaga, profesi, dan kedudukan sesuai dengan kepercayaan yang menjadi tanggungjawabnya; dan (3) meningkatkan kemampuan professional yang meliputi kemampuan intelektual, integritas kepribadian dan interaksi sosial baik di lingkungan kerja maupun di masyarakat. Menurut Subarsono (2005:67) menyatakan bahwa "sekolah menyediakan sarana dan prasarana yang memungkinkan tercapainya tujuan sekolah dan tuntutan pedagogik yang diperlukan untuk menjamin terselenggaranya proses pendidikan yang bermakna, menyenangkan, dan memberdayakan sesuai tuntutan karakteristik mata pelajaran, pertumbuhan dan perkembangan efektif, kognitif, psikomotor peserta didik. Sekolah menyediakan sarana dan prasarana yang diperlukan untuk menyelenggarakan program penddidikan. Penyediaan sarana dan prasarana yang memenuhi tuntutan pedagogik diperlukan untuk menjamin terselenggaranya proses pendidikan yang bermakna, menyenangkan, dan memberdayakan afektif, kognitif, psikomotor peserta didik. Sekolah memiliki sarana dan prasarana yang meliputi gedung, ruang pimpinan, ruang tata usaha, ruang kelas, laboratorium, perpustakaan, pusat sumber pembelajajaran, ruang praktek, media pembelajaran, bahan/material, sarana pendidikan jasmani dan olah raga, tempat beribadah, tempat bermain, tempat berkreasi dan rekreasi, fasilitas kesehatan dan keselamatan bagi para peserta didik dan penyelenggara pendidikan, dan sarana serta prasarana lain sesuai tuntutan program-program pendidikan yang diselnggarakan oleh sekolah.

Sekolah memiliki dana pendidikan yang cukup dan berkelanjutan untuk menyelenggarakan proses belajar mengajar yang bermutu di sekolah. Sekolah menghimpun dana dari berbagai potensi sumber dana. Sekolah mengelola dana pendidikan secara transparan, efisien, dan akuntabel sesuai dengan prinsip manajemen berbasis sekolah. Menurut Simmons (2008:891) menyatakan bahwa "dalam mengalokasikan dana pendidikan, sekolah berpegang pada prinsip keadilan dan pemerataan". Sekolah memiliki dana yang cukup untuk menyelenggarakan pendidikan. Sekolah menggunakan dana yang tersedia untuk terlaksananya proses belajar mengajar yang bermutu. Dalam menghimpun dana, sekolah perlu memperhatikan semua potensi sumber dana yang ada seperti subsidi pemerintah, sumbangan masyarakat dan orang tua peserta didik, hibah, dan sumbangan lainnya. Pengelolaan dana pendidikan di sekolah harus dilakukan secara transparan, efisien, dan akuntabel sesuai dengan prinsip manajemen berbasis. Dana pendidikan disekolah dialokasikan berdasarkan keadilan dan pemerataan yaitu tidak diskriminatif terhadap anggaran biaya yang diperlukan untuk masing-masing kegiatan sekolah. Menurut Suratman (1992:343) menyatakan bahwa "Standar peserta didik mencakup: (a) penerimaan, pengembangan, dan pembinaan 
peserta didik, serta (b) keluaran. Sementara penerimaan dan Pengembangan Peserta didik didasarkan atas criteria yang jelas, transaparan dan akuntabel. Peserta didik memiliki tingkat kesiapan belajar yang memadai, baik mental maupun fisik. Sekolah memiliki program yang jelas tentang pembinaan, pengembangan, dan pembimbingan peserta didik. Sekolah member kesempatan yang luas kepada peserta didik untuk berperanserta dalam penyelenggaraan program sekolah. Sekolah melakukan evaluasi kemajuan dan hasil belajar peserta didik yang memenuhi kaidah evaluasi yang baik. Peserta didik adalah warga masyarakat yang berusaha mengembangkan potensi dirinya melalui proses pembelajaran pada satuan pendidikan tertentu. Peserta didik merupakan salah satu masukan yang sangat menentukan bagi berlangsungnya proses pembelajaran. Namun demikian prestasi belajar yang dicapai oleh peserta didik pada dasarnya merupakan upaya kolektif antara peserta didik dan guru.

\section{METODE PENELITIAN}

Sesuai dengan permasalahan dalam penelitian ini yaitu Pelaksanaan Akreditasi Sekolah Dasar Negeri Nomor 9 Semadai Di Desa Tanjung Bunga Kecamatan Kayan Hulu, maka peneilitian ini adalah peneilitain lapangan dan didukung oleh subjek pnelitian Kepala Dinas Pendidikan Kabupaten Sintang, Kepala Cabang Dinas Pendidikan Kecamatan Kayan Hulu, Pengawas Sekolah Dasar Kecamatan Kayan Hulu, Kepala Sekolah Dasar Negeri 9 Semadai, Guru Sekolah Dasar Negeri 9 Semadai, Ketua Komite Sekolah, Siswa Sekolah Dasar Negeri 9 Semadai Adapun teknik pengumpulan data yanag penulis gunakan dalam penelitian ini adalah Wawancara, Observasi dan Studi Dokumentasi

\section{HASIL DAN PEMBAHASAN}

Sekolah Dasar Negeri 9 Semadai Kecamatan Kayan Hulu Kabupaten Sintang berdiri pada Tahun 1993. Sejarah perkembangan mengenai perubahan nama Sekolah Dasar Negeri 9 Semadai adalah sebagai berikut: Awal mulanya Sekolah Dasar Negeri 9 Semadai Desa Tanjung Bunga sejak berdirinya pada tahun 1993 di rintis oleh pemerintah daerah melalui pemerintah Kecamatan Kayan Hulu bekerjasama dengan Kepala Desa Tanjung Bunga yang di kelola secara swadaya awalnya dengan dana dari pemerintah dan melibatkan masyarakat setempat. Sekolah Dasar Negeri 9 Semadai Desa Tanjung Bunga ini berdiri mulai tahun 1993 dengan pendirinya adalah dimotori oleh Kepala Desa dengan mengajukan permohonan ke tingkat Kecamatan.

Kepala Sekolah Dasar Negeri Nomor 9 Semadai pertama di angkat dari salah satu guru yang ada di Kecamatan Kayan Hulu. Selama masa kepemimpinan beliau, Sekolah Dasar Negeri 9 Semadai ini merupakan sekolah Dasar Negeri pertama yang memiliki fasilitas gedung dan ruang belajar yang memadai dari pemerintah Kecamatan Kayan Hulu. Para siswa juga di bekali dengan berbagai keterampilan yang mendukung. Dengan pertimbangan bahwa semua siswa Sekolah Dasar Negeri 9 Semadai memiliki dan mendapatkan pengetahuan umum baik tentang belajar di sekolah maupun kegiatan ekstra atau tentang pengetahuan luar sekolah yakni tentang muatan lokal yang sangat mendukung kemajuan peningkatan pengetahuan siswa. Kemudian setelah mengalami berbagai tuntutan dan perkembangan kurikulum sejak tahun1997 Sekolah Dasar Negeri 9 Semadai berusaha membenah kurikulum agar siswa bisa bersaing dengan sekolah Dasar lainnya di Kecamatan Kayan Hulu. Sebagai akibat dari tuntutan kurikulum pembelajaran yang selalu mengalami perubahan, maka pada tahun 1998 Sekolah Dasar Negeri 9 Semadai juga mengikuti perubahan kurikulum seperti Cara Belajar Siswa Aktif yang sekarang berubah menjadi Kurikulum Tingkat satuan Pendidikan.

Secara geografis Sekolah Dasar Negeri 9 Semadai terletak di Kecamatan Kayan Hulu yang mana sekolah ini merupakan satu sekolah yang di kelola secara swadaya awalnya dan kemudian menjadi sekolah negeri. Dari depan sekolah berhadapan langsung dengan jalan utama akses perekonomian masyarakat. Sekolah Dasar Negeri 9 Semadai dikategorikan dalam letak yang sangat strategis karena berada diposisi pertengahan desa di daerah Tanjung Bunga serta tidak jauh dari pertemuan antara muara sungai Kayan yang sering digunakan masyarakat sebagai jasa transportasi air maupun untuk akses perekonomian masyarakat. Dengan memiliki letak geografis yang sangat strategis demikian, maka tidak jarang Sekolah Dasar 9 Semadai dapat menarik simpati masyarakat luas yang lalu lintas dijalan raya. Kondisi geografis seperti itulah yang sering dimanfaatkan oleh para siswa untuk melaksanakan kegiatan diluar jam sekolah misalnya dengan mengadakan kunjungan persahabatan ke sekolahsekolah terdekat.

Sekolah Dasar Negeri 9 Semadai merupakan sekolah negeri yang dibina langsung oleh Cabang Dinas Pendidikan Kecamatan Kayan Hulu yang berkedudukan atau bertempat di Kecamatan Kayan Hulu, Kabupaten Sintang. Dengan kedudukan dan tempat ditengah pusat Desa Tanjung Bunga yang padat dan strategis ini, maka Sekolah Dasar Negeri 9 Semadai selalu siap mengembangkan diri sesuai dengan tuntutan dan perkembangan di era globalisasi. 
Terdapat beberapa prosedur berkaitan dengan prinsip-prinsip akriditasi sekolah. Prosedur dan mekanisme pelaksanaan akreditasi sekolah sebagaimana digambarkan di atas dapat dijelaskan bahwa sebelum mengajukan permohonan akreditasi, sekolah harus melakukan evaluasi diri terlebih dahulu. Evaluasi diri dilakukan melalui pengisian instrument evaluasi diri yang diterbitkan oleh Badan Standar Nasional. Instrument tersebut dapat diperoleh dari berbagai sumber, seperti BASNAS, BAS Provinsi atau BAS Kabupaten / Kota. Instrument evaluasi diri juga tersedia dalam program SIAS dan website BASNAS. Sekolah yang telah melakukan evaluasi diri dan siap untuk diakreditasi mengajukan permohonan kepada BAS Provinsi untuk jenjang SLB, SMA, dan SMK atau kepada BAS Kabupaten untuk jenjang TK, SD, atau SMP. Di samping menyerahkah instrument evaluasi diri, pada saat mengajukan permohonan, sekolah harus melampirkan surat persetujuan atau rekomendasi dari dinas pendidikan terkait. Rekomendasi diperlukan untuk mengetahui bahwa sekolah yang mengajukan akeditasi diasumsikan telah memenuhi persyaratan untuk mengikuti proses akreditasi sesuai dengan standar akreditasi yang ditetapkan.

Instrument evaluiasi diri yang telah diisi oleh sekolah selanjutnya diolah oleh tim teknis BAS untuk menentukan apakah sekolah tersebut layak untuk dilakukan visitasi atau tidak. Pengertian layak dalam hal ini adalah tercapainya nilai minimal serta terpenuhinya criteria yang telah ditetapkan oleh BAS. Apabila hasil evaluasi diri tidak memenuhi persyaratan kelayakan dan criteria yang ditentukan, maka BAS memutuskan untuk tidak melakukan visitasi ke sekolah. Bagi sekolah yang tidak dilakukan visitasi, BAS akan menyampaikan informasi ke Dinas Pendidikan, untuk selanjutnya dapat dilakukan pembinaan dan perbaikan internal. Perbaikan internal tersebut dilakukan dengan mengacu pada hasil evaluasi diri terhadap seluruh komponen akreditasi sekolah. Sekolah yang tidak dilakukan visitasi tersebut dapat mengajukan kembali untuk dilakukan akreditasi segera setelah membenahi diri dan siap di akreditasi. Dengan menggunakan instrument visitasi, tim asesor (yang terdiri dari beberapa orang) melakukan kunjungan ke sekolah . kegiatan-kegiatan tersebut dapat dilaksanakan melalui pengamatan lapangan, wawancara dengan warga sekolah, verifikasi atau pencermatan ulang berbagai data pendukung, serta pendalaman hal-hal khusus yang berkaitan dengan komponen dan aspek akreditasi. Visitasi ini dilakukan untuk meningkatkan kecermatan, keabsahan, serta kesesuaian antara fakta dengan data yang diperoleh melalui pengisian instrument evaluasi diri.

Di samping itu, dengan visitasi ini diharapkan dapat diperoleh data dan informasi tambahan mengenai keadaan yang sesungguhnya dari sekolah yang diakreditasi. Hasil wawancara dengan Kepala Cabang Dinas Pendidikan Kecamtan Kayan Hulu mengatakan bahwa pelaksanaan visitasi berpegang pada prinsip-prinsip: efektif, artinya mampu menjaring informasi yang akurat dan valid sebagai daras pengambilan keputusan yang tepat bagi semua pihak yang memerlukannya. Efisien, artinya dibatasi pada hal-hal yang pokok, namun cukup memberikan gambaran yang utuh dan terfokus pada substansi yang telah ditetapkan, Objektif, artinya berdasarkan kenyataan pada sejumlah indicator yang dapat diamati, Mandiri, artinya mendorong sekolah untuk melakukan evaluasi diri secara akurat sebagai salah satu fungsi pokok manajemen penyelenggaraan sekolah dalam rangka pemberdayaan sekolah. Sebelum melaksanakan kegiatan visitasi, BAS menerbitkan surat tugas kepada asesor yang ditunjuk sesuai kebutuhan, menyiapkan instrument evaluasi diri yang telah diisi oleh sekolah dan dokumen lainnya, sehingga dapat mendukung hasil akreditasi yang komprehensif, valid, dan akurat, serta dapat memberikan manfaat, maka kegiatan visitasi harus mengikuti tata cara pelaksanaan. Tatacara pelaksanaan visitasi yakni Badan Akriditasi Sekolah menunjuk dan mengirimkan asesor. Asesor diangkat oleh BAS untuk melaksanakan tugasnya sesuai dengan mekanisme, prosedur, norma, dan waktu pelaksanaan yang telah ditetapkan. Sebelum melaksanakan visitasi, asesor mempelajari dan mencermati hasil evaluasi diri yang telah dilakukan dengan memberikan catatan pada setiap komponen dan aspek akreditasi sekolah, sehingga asesor memiliki pengetahuan awal tentang kondisi dan kinerja sekolah.

Sesuai dengan surat tugas dari BAS, asesor akan melakukan visitasi ke sekolah yang akan diakreditasi. Asesor akan dating ke sekolah menemui kepala sekolah dan warga sekolah dan menyampaikan tujuan dari visitasi, melakukan klarifikasi, verifikasi dan validasi atau cek ulang terhadap data dan informasi kuantitatif maupun kualitatif yang terjaring melalui instrument evaluasi diri. Kegiatan klarifikasi, verifikasi dan validasi tersebut dilakukan dengan cara membandingkan data dan informasi yang telah diperoleh melalui instrument evaluasi diri dengan kondisi nyata sekolah. Melalui pengamatan lapangan, observasi kelas, wawancara dengan warga sekolah, dan pencermatan ulang data pendukung. Tim asesor juga dimungkinkan untuk melakukan pencarian data dan informasi tambahan yang esensial tentang sekolah, dan termasuk pendalaman hal-hal khusus untuk memperkuat hasil klarifikasi, verifikasi dan validasi yang dilakukannya. Klarifikasi temuan ini dimaksudkan untuk menyampaikan secara umum gambaran yang diperoleh asesor untuk setiap komponen dan aspek untuk dijadikan bahan perbaikan bagi sekolah di masa mendatang. Klarifikasi ini bukan merupakan lanhkah kompromi 
antara tim asesor dengan sekolah untuk memperoleh peringkat akreditasi secara tidak benar. Berdasarkan hasil klarifikasi, verifikasi, validasi dan pendalaman terhadap data dan informasi tambahan serta didukung oleh berbagai data dan informasi penting lainnya, maka masing-masing anggota tim asesor menyusun laporan individual. Laporan individual ini memuat nilai dan catatan untuk masing-masing komponen akreditasi yang dibuat berdasarkan deskripsi yang telah ditetapkan dalam sistem penilaian.

Laporan individual tersebut selanjutnya dijadikan bahan untuk didiskusikan bersama-sama dengan anggota tim asesor lainnya untuk menyusun laporan tim tentang pelaksanaan visitasi. Dalam diskusi tersebut dibahas berbagai komponen, aspek dan indicator akreditasi sesuai dengan hasil verifikasi, validasi, dan poendalaman data dan informasi untuk menetapkan laporan akhir dan perumusan rekomendasi. Penyerahan Laporan. Laporan tim asesor yang mencakup hasil penilaian visitasi yang dilengkapi dengan pernyataan kepala sekolah tentang pelaksanaan visitasi dan saran-saran pembinaan, pengembangan, dan peningkatan kinerja sekolah akan disampaikan oleh tim asesor kepada BAS. Laporan tim asesor tersebut harus dilampiri dengan laporan individual masing-masing asesor. Penyerahan laporan tim asesor tersebut dilakukan segera setelah visitasi dilaksanakan. Laporan tim asesor merupakan dokumen penting yang akan dihimpun dan menjadi arsip BAS. Laporan ini dipergunakan oleh BAS sebagai bahan pertimbangan untuk menetapkan hasil dan peringkat akreditasi sekolah termasuk perumusan rekomendasi untuk pembinaan, pengembangan dan peningkatan mutu kelayakan dan kinerja sekolah. Untuk pelaksanaan visitasi, BAS mengangkat tim asesor yang memenuhi criteria yang telah ditentukan. Jumlah anggota tim asesor disesuaikan dengan kebutuhan dengan jumlah minimal 2 orang untuk setiap sekolah. Asesor diangkat untuk periode tertentu sesuai surat tugas yang dikeluarkan oleh BAS dan dapat diangkat kembali jika berdasarkan hasil evaluasi kenerjanya dianggap layak untuk melaksanakan tugas tersebut. Asesor tidak memenuhi tanggung jawab untuk melaksanakan tugasnya secara. Sungguh-sungguh dengan berpedoman kepada norma-norma pelaksanaan visitasi, sehingga hasil akreditasi yang diberikan kepada sekolah benar-benar mencerminkan tingkat kelayakan dan kinerja sekolah yang sesungguhnya. Visitasi disekolah dilaksanakan antara 3 sampai dengan 5 hari kerja. Perpanjangan waktu visitasi dapat diberikan oleh BAS, apabila hal tersebut dipandang perlu. Hasil visitasi harus dilaporkan oleh tim asesor sesegera mungkin dan paling lambat satu minggu setelah penugasan visitasi berakhir. Laporan tim asesor yang memuat hasil visitasi, catatan verifikasi dan rumusan saran bersama dengan hasil evaluasi diri akan diolah oleh BAS untuk menetapkan nilai akhir dan peringkat akreditasi tersebut dilakukan melalui rapat pleno BAS provinsi atau BAS Kabupaten/Kota sesuai dengan kewenangannya. Rapat pleno penetapan hasil akhir akreditasi harus dihadiri oleh sekurang-kurangnya lebih dari lima puluh persen anggota BAS. Keputusan penetapan hasil akreditasi ditetapkan melalui musyawarah untuk mufakat. Hasil rapat pleno Badan Akreditasi Sekolah tentang penetapan hasil akreditasi dituangkan dalam bentuk surat keputusan Badan Akreditasi Sekolah. Nilai akhir dan peringkat akreditasi tersebut juga dilengkapi dengan penjelasan atau informasi kualitatif tentang kekuatan dan kelemahan masing-masing koponen dan aspek akreditasi, termasuk saran-saran tindak lanjut bagi sekolah, dinas pendidikan, maupun departemen pendidikan nasional. Penjelasan kualitatatif dan saran-saran tersebut harus bersifat spesifik agar mempermudah pihak sekolah untuk melakukan pengembangan dan perbaikan internal dan pihak terkait, dalam hal ini pemerintah daerah dan dinas pendidikan, dalam melakukan pemberdayaan dan pembinaan lebih lanjut.

Hasil akreditasi yang ditetapkan melalui rapat pleno, BAS Provinsi atau BAS Kabupaten/Kota sesuai dengan kewenangannya akan menerbitkan sertifikat akreditasi sekolah sesuai dengan format dan blanko yang dikeluarkan oleh BASNAS. Sertifikat akreditasi memuat nilai masing-masing komponen (dalam angka) dan peringkat/status akreditasi sekolah yang dinyatakan dengan huruf A (amat baik), B (baik), dan C (cukup). Status akreditasi ini berlaku untuk kurun waktu 4 tahun sejak tanggal ditetapkannya. Setalah periode 4 tahun sekolah harus diakredirtasi ulang. Disamping sertifikat akreditasi, BAS juga memberikan laporan lengkap hasil akreditasi kepada sekolah. Laporan hasil akreditasi memuat antara lain: data dan profil sekolah, nilai untuk setiap komponen akreditasi, kekuatan dan kelemahan untuk setiap komponen akreditasi, serta saran untuk pengembangan dan perbaikan sekolah. Berdasarkan hasil akreditasi dan rekomendasi yang ditetapkan oleh BAS, sekolah melakukan perbaikan dn peningkatan kelayakan pelayanan dan kinerjanya dengan bantuan dinas pendidikan provinsi dan/atau Dinas Pendidikan Kabupaten/Kota, serta Departemen Pendidikan Nasional.

Persyaratan Sekolah yang diakritasi harus memenuhi persyaratan memiliki surat keputusan kelembagaan unit pelaksana teknis (UPT) sekolah, memiliki siswa pada semua tingkatan kelas, memiliki sarana dan prasarana pendidikan, memiliki tenaga kependidikan, melaksanakan kurikulum nasional dan telah menamatkan peserta didik. Dalam pelaksanaan akriditasi sekolah telah memiliki standar akriditasi tertuang dalam Peraturan Menteri Pendidikan Nasional Nomor. 52 Tahun 2008 tentang Kriteria dan Perangkat Akreditasi Sekolah, Peraturan Menteri Pendidikan Nasional Nomor. 29 
Tahun 2005 tentang Badan Akreditasi Nasional Sekolah-Madrasah serta Kebijakan Akreditasi Sekolah (Bahan Pelatihan Asesor Akreditasi SMP-MTs Tahun 2009). Proses evaluasi terhadap seluruh aspek pendidikan harus diarahkan pada upaya untuk menjamin terselenggaranya leyanan pendidikan yang bermutu dan memberdayakan sekolah yang dievaluasi sehingga dihasilkan lulusan pendidikan sesuai dengan standar yang ditetapkan. Artinya pihak yang dievaluasi, administrator pendidikan, kepala sekolah, guru, dan peserta didik didalam suatu satuan pendidikan dapat merasakan bahwa kegiatan evaluasi dapat member informasi mengenai berbagai kelebihan dan kekurangan, serta memberikan arah yang jelas untuk mencapai mutu yang lebih baik. Untuk itu, evaluasi harus dilakukan secara berkesinambungan dan komprehensif, serta memotivasi peserta didik dan pengelola pendidikan untuk terus menerus berupaya meningkatkan mutu pendidikan.

Data akreditasi yang berupa nilai akhir dan peringkat akreditasi sekolah termasuk berbagai data tambahan yang esensial akan diolah dan diadministrasikan sebagai sistem database dengan menggunakan suatu system informasi yang disebut dengan system informasi akreditasi sekolah, disingkat SIAS. Dengan sistem ini, BASNAS mengembangkan dan mengelola database hasil akreditasi setiap sekolah. Selanjutnya, database hasil akreditasi tersebut akan dapat diolah sesuai kebutuhan dan diperlukan untuk mengetahui perkembangan pemetaan mutu pendidikan secara nasional. Selain itu, data yang terkumpul melalui proses akreditasi sekolah ini dapat diolah sebagai database individual sekolah yang dapat dijabarkan menjadi profil individual sekolah. Berdasarkan profil sekolah inilah, selanjutnya akan dapat dikaji profil pendidikan daerah tertentu maupun profil pendidikan secara nasional. Hasil akreditasi dan informasi tentang profil pendidikan tersebut dapat diakses secara bebas bagi yang memerlukan, tetapi tidak dapat dimodifikasi oleh pengaksesnya tanpa otoritas dari BAS. Pelaksanaan akreditasi sekolah harus berpedoman kepada norma-norma yang sesuai dengan tujuan dan fungsi akreditasi. Normanorma ini harus menjadi pegangan dan komitmen bagi semua pihak yang terlibat didalam proses akreditasi. Dalam menyampaikan data dan informasi dalam pelaksanaan evaluasi diri dan visitasi, pihak sekolah harus secara jujur menyampaikan semua data dan informasi yang dibutuhkan. Sekolah harus memberikan kemudahan administratif dengan menyediakan data yang diperlukan, mengizinkan tim asesor melakukan pengamatan, wawancara dengan warga sekolah, dan pengkajian ulang data pedukung.

Sebagian besar guru selalu menggunakan metode mengajar yang bervariasi dalam proses belajar sehingga siswa dapat mengerti dan memahami materi yang disampaikan oleh bapak/ibu guru. Adapun metode yang sering digunakan oleh guru adalah metode ceramah, Tanya jawab, diskusi dan sisiodrama (guru meminta siswa bisa mempraktektikan karakter dalam cerita). Dari wawancara tersebut juga diketahui masih ada sebagian guru yang belum menbuat silabus atau rencana pembelajaran dengan baik. Belakangan ini diketahui bahwa sebagian guru tidak membuat silabus atau rencana pembelajaran karena kurikulum selalu diubah oleh pemerintah setiap tahun, sedangkan sosialisasinya jarang dilakukan oleh pemerintah. Disisi lain dikemukakan bahwa untuk membuat silabus atau rencana pembelajaran memerlukan waktu dan biaya yang cukup banyak. Agar mutu pendidikan dan proses belajar mengajar dapat berlangsung secara efektif dan efisien, maka Sekolah Dasar Negeri 9 Semadai memiliki guru 9 (sembilan) orang. Jumlah guru tersebut di anggap masih sangat jauh dari kurang di bandingkan dengan jumlah kelas dan siswa yang ada. Penempatan seorang guru pada bidangnya merupakan prioritas utama bagi Sekolah Dasar Negeri 9 Semadai dalam mendidik siswanya untuk menjadi manusia yang terampil dan berbudi mulia sesuai dengan tuntutan ilmu pengetahuan. Seorang guru dikatakan ideal apabila telah dapat menjalankan tugas dengan sebaik-baiknya. Tugas yang diemban oleh seorang guru dalam membina siswanya tidaklah mudah yakni harus berhadapan langsung dengan siswa dalam kegiatan belajar mengajar. Kesanggupan seperti ini mau tidak mau harus diterima dan dijalankan.

Berdasarkan hasil temuan yang peneliti lakukan bahwa ada sebagian guru Sekolah dasar Negeri 9 Semadai belum membuat silabus/rencana pembelajaran sebelum mengajar. Alasan dikemukakan opleh bapak dan ibu guru, mengenai pembuatan silabus/rencana pembelajaran karena kebijakan pemerintah dalam menetapkan pemakaian kurikulum. Menurut para guru akhirakhir ini kurikulum terus berubah setiap tahunnya sehingga menyulitkan guru. Menurut hasil penelitian yang penulis lakukan dilokasi penelitian, masih ditemukan kekurangan sarana dan prasarana yang mendukung kegiatan proses belajar mengajar oleh guru dikelas maupun untuk kegiatan di luar sekolah sesuai kebutuhan sekolah seperti untuk pelajaran Ilmu Pengetahuan Alam alat praktek hampir tidak ada. Sebagian meja kursi mulai rusak akibat termakan usia yang cukup lama. Selain itu peralatan-peralatan yang sering digunakan oleh siswa dalam praktik seharusnya ada namun kenyataannya belum terpenuhi secara maksimal. Ruangan laboratorium tidak ada serta jumlah sarana kantor seperti mesin ketik yang harus digunakan oleh pegawai Tata Usaha Sekolah Dasar Negeri 9 Semadai belum memadai apalagi komputer tidak ada mengingat harganya semakin mahal. Menurut 
pengakuan siswa bahwa sering tidak aktifnya beberapa gur untuk melaksanakan praktik di lapangan dalamkegiatan ekstra sekolah atau ruang praktik karena keterbatasan jumlah alat peraga yang idealnya untuk satu orang meggunakan satu untuk banyak siswa seperti praktek memegang dan mempelajari bola Global dunia. Namun kenyataan tersebut terbalik, dengan satu bola global jumlah siswa bisa dua atau tiga orang. Dengan kurangnya sarana dan prasarana tersebut akan mempengaruhi efektivitas proses belajar mengajar. Keberadaan sarana dan prasarana yang mendukung kegiatan praktik siswa akan sangat membantu kelancaran dalam peningkatan motivasi dan mutu pendidikan siswa.

Biaya pelaksanaan kegiatan akreditasi sekolah menjadi tanggung jawab pemerintah dan pemerintah daerah melalui anggaran pedapatan belanja Negara (APBN) dan anggaran pendapatan belanja Daerah (APBD). Dalam pelaksanaan akreditasi, sekolah dilarang mengeluarkan biaya apapun. Tatacara pengelolaan dan pertanggung jawaban keuangan kegiatan akreditasi sekolah berpedoman pada prinsip efisiensi, efektivitas, keterbukaan, akuntanbilitas, sesuai dengan peraturan perundang-undangan yang berlaku. Berdasarkan hasil wawancara yang telah dilakukan oleh peneliti kepada Kepala Sekolah Dasar Negeri 9 Semadai, bahwa sumber dana yang diperoleh dari pihak sekolah meliputi sumbangan pembangunan pendidikan dalam bentuk dana Komite dari siswa dan sumbangan dari pihak pemerintah yang menunjang operasional pendidikan seperti bassed broad education (BBE), Community college (CC) dan bea operasional sekjolah (BOS) serta Bantuan Operasional Sekolah (BOS). Dengan melihat sangat minimnya sumber pemasukan dana bagi peningkatan mutu pendidikan sesuai standar nasional pendidikan maka sangat berpengaruh atau menghmbat perkembangan sekolah. Sumbangan pembangunan pendidikan dalam bentuk dana komite yang merupakan sumber dana pendukung bagi sekolah sangat menyulitkan sekolah untuk mengadakan barang-barang atau fasilitas-fasilitas yang telah rusak. Sebagian besar siswa Sekolah Dasar Negeri 9 Semadai berasal dari pedalaman dengan tingkat ekonomi menengah ke bawah dan berasal dari keluarga tidak mampu.

\section{KESIMPULAN}

Berdasarkan hasil penelitian yang telah dilakukan maka dapat ditarik kesimpulan sebagai berikut :Pelaksanaan akreditasi sekolah secara umum telah dijalankan dengan baik. Dalam pelaksanaan akreditasi sekolah terdapat prinsipprinsip akrditasi sekolah yang harus dijalankan.
Adanya standar akreditasi sekolah yang juga menjadi acuan bagi asesor dan sekolah yang divisitasi. Dalam pelaksanaan akreditasi sekolah juga tetap memperhatikan komponen-komponen yang diakreditasi. Kendala yang terjadi dilapangan berkaitan dengan pelaksanaan akreditasi sekolah adalah seringkali dilakukan tanpa persiapan sekolah yang matang. Surat dari BAS dilayangkan secara mendadak, akibatnya sekolah tidak bisa mempersiapkan materi yang divaluasi secara optimal. Faktor-faktor yang mempengaruhi pelaksanaan tugas guru yaitu tenaga guru yang sangat erat dengan sumber daya manusiannya. Sarana penunjang kegiatan belajar mengajar yang masih sangat kurang keberadaannya, serta kurangnya dana pendukung kegiatan operasional sekolah yang masih dirasakan oleh pihak sekolah. Pihak sekolah mengalami kesulitan dalam pembangunan dan pengembangan infrastruktur, fasilitas-fasilitas penunjang guru dan mutu pendidikan serta peningkatan peranserta masyarakat dalam pengebangan pendidikan di sekolah tersebut.

\section{DAFTAR PUSTAKA}

Arikunto,S, 1998. Prosedur Penelitian. Jakarta: Rinika Cipta.

Hadi,S.1985. Pendekatan Luar Sekolah di Dalam Sistem Pendidikan dan

Pembangunan Nasional. Surabaya: Usaha Nasional.

Jopham, 1992. Teknik Mengajar Secara Sistematis. Jakarta:

Renika Cipta.

Luhulima, 2007. Dasar dan Teknik Reseach

Pendidikan Dasar. Bandung: Penerbit Tarsito.

Mangunwijaya, 2004. Pendidikan Pemerdikaan. Yoyagkarta: Dinamika Edukasi Dasar

Moleong, 1988. Metodologi Penelitian Kualitatif. Bandung: PT. Remaja

Rosdakarya.

Riyadi,2005. Monetoring dan evakuasi Proyek Pendidikan .Jakarta: Dunia

Pustaka Jaya.

Samodera. 2000. Teori Perencanaan Pendidikan. Yogyakarta: Adicita

Karya Nusa.

Simmons, 2008. Monetoring dan evakuasi Proyek Pendidikan .Jakarta: Dunia

Pustaka Jaya. 
Soekartawi, 1994. Monetoring dan evakuasi Proyek Pendidikan .Jakarta: Dunia Pustaka Jaya.

Suratman, 1992. Monetoring dan evakuasi Proyek Pendidikan .Jakarta: Dunia Pustaka Jaya.

\section{Peratran dan Perundang-Undangan:}

Keputusan Menteri Pendidikan Nasional Nomor 087 Tahun 2002 Tentang Akreditasi Sekolah
Peraturan Pemerintah Nomor 25 Tahun 2000 Tentang Kewajiban Pemerintah dan Kewenangan Propinsi

Undang-Undang Republik Indonesia Nomor 22 Tahun 1999

Undang-Undang Republik Indonesia Nomor 32 Tahun 2004 Tentang Pemerintah Daerah

Undang-Undang Nomor 20 Tahun 2003.Tentang Sistem Pendidikan Nasional. 